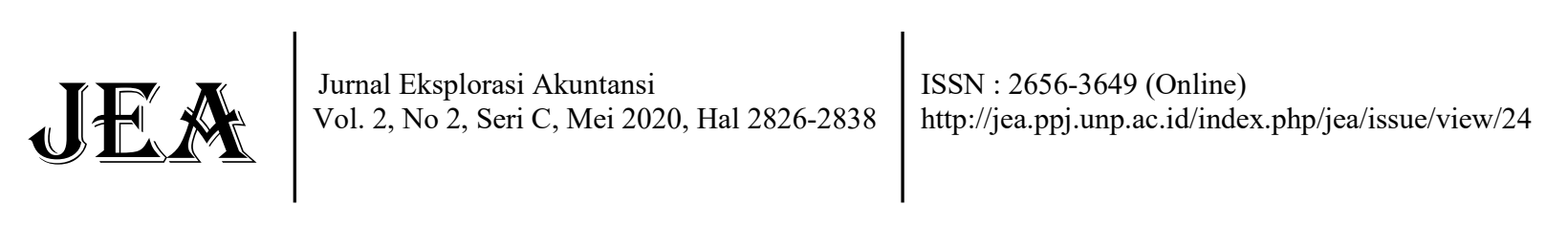

\title{
ANALISIS FLYPAPER EFFECT PADA DANA ALOKASI UMUM, DANA ALOKASI KHUSUS, DANA BAGI HASIL DAN PENDAPATAN ASLI DAERAH TERHADAP BELANJA DAERAH KABUPATEN/KOTA DI SUMATERA BARAT
}

\author{
Helmi Melda ${ }^{1}$, Efrizal Syofyan ${ }^{2}$ \\ ${ }^{1}$ Alumni Jurusan Akuntansi Fakultas Ekonomi, Universitas Negeri Padang \\ ${ }^{2}$ Jurusan Akuntansi Fakultas Ekonomi, Universitas Negeri Padang \\ *Korespondensi: helmimelda211@gmail.com
}

\begin{abstract}
Abstrak: Tujuan dari penelitian ini adalah untuk mengetahui pengaruh dana alokasi umum, dana alokasi khusus dan dana bagi hasil terhadap belanja daerah serta analisis flypaper effect pada Pemerintah kabupaten/kota di Sumatera Barat. Populasi dalam penelitian ini adalah kabupaten/kota di Sumatera Barat yang terdiri dari 19 kabupaten/kota selama periode 20152018. Metode yang digunakan dalam penelitian ini adalah regresi berganda dengan perangkat lunak spss. Hasil dari penelitian ini adalah, pertama menunjukkan bahwa secara parsial variabel dana alokasi umum, dan alokasi khusus dan pendapatan asli daerah berpengaruh positif signifikan terhadap belanja daerah, sedangkan variabel dana bagi hasil tidak berpengaruh terhadap belanja daerah pada Kabupaten/Kota di Sumatera Barat. Serta hasil pengujian menunjukkan koefisien dana transfer lebih besar daripada koefisien pendapatan asli daerah yang menunjukkan bahwa terjadi flyapaper effect pada pemerintah kabupaten/kota di sumatera barat.
\end{abstract}

Kata kunci: dana alokasi umum; dana alokasi khusus; dana bagi hasil; pendapatan asli daerah; flypaper effect

How to cite (APA $6^{\text {th }}$ style):

Melda, Helmi \& Syofyan. Efrizal. (2020). Analisis Flypaper Effect Pada Dana Alokasi Umum, Dana Alokasi Khusus, Dana Bagi Hasil Dan Pendapatan Asli Daerah Terhadap Belanja Daerah Kabupaten/Kota Di Sumatera Barat. Jurnal Eksplorasi Akuntansi, 2(2), Seri C, 2826-2838.

\section{PENDAHULUAN}

Penerapan Otonomi daerah di Indonesia berlaku semenjak disahkannya Undang-Undang No 32 dan 33 tahun 2004 tentang Pemerintah Daerah dan tentang Perimbangan Keuangan Antara Pemerintah Pusat dan Pemerintah Daerah. Otonomi daerah bertujuan untuk mewujudkan kemandirian pemerintah di daerah tanpa ada bergantung ke Pemerintah Pusat. Diberlakukannya 
otonomi daerah menyebabkan Pemerintah daerah memiliki wewenang dan tanggungjawab untuk memenuhi kebutuhan masyarakat dan pemdanya masing-masing.

Wujud dari penerapan otonomi daerah adalah diterapkannya desentralisasi fiskal ternyta membuat pemerintah daerah bergantung kepada pemerintah pusat, hal ini terjadi karena pemerintah pusat memberikan dana perimbangan ke pemerintah daerah dengan tujuan menyamaratakan kemampuan keuangan daerah malah lebih banyak dibandingkan pendapatan asli daerahnya, inilah yang kemudian menjadi penyebab terjadi fenomena flypaper effect pada Pemerintah daerah. Flypaper Effect adalah kondisi dimana pemerintah daerah menggunakan pembiayaan untuk belanja daerah lebih tinggi berasal dari dana perimbangan atau dana transfer dibandingkan pendapatan asli daerahnya sendiri, dana transfer yang dimaksud adalah transfer tak bersyarat yang terdiri dari dana alokasi umum, dana alokasi khusus, dan dana bagi hasil, dan inilah yang kemudian menjadi pemborosan dalam belanja daerah (Octavia, 2014).

Flypaper effect sendiri secara umum diartikan sebagai suatu kondisi yang terjadi pada pemerintah daerah dimana pemda lebih banyak menggunakan atau memanfaatkan transfer yang berasal dari dana alokasi umum dibandingkan pendapatan asli daerah dalam hal penggunaan untuk belanja daerah.Syarat terjadinya fenomena flypaper Effect yaitu ketika pada hasil pengujian diperoleh besarnya nilai koefisien dana transfer yang lebih tinggi jika dibandingkan dengan koefisien pendapatan asli daerah, dan dapat dikatakan terjadi flypaper effect jika koefisien pendapatan asli daerah tidak signifikan (Maimunah, 2006). Asumsi penentuan terjadi atau tidaknya fenomena flypaper effect adalah dengan membandingkan antara pengaruh pendapatan asli daerah serta dana transfer pada belanja daerah.

Penelitian yang dilakukan Kusumadewi dan Rahman pada tahun 2017 menyatakan bahwa fenomena flypaper effect terjadi pada daerah yang memiliki tingkat pendapatan asli daerah yang tinggi dan terjadi pula pada daerah yang tingkat pendapatan asli daerahnya rendah, dan terdapat fenomena flypaper effect dalam kinerja pemerintah provinsi, yang dibuktikan dengan lebih besarnya pengaruh dana alokasi umum dibandingkan dengan pengaruh pendapatan asli daerah terhadap belanja daerah. Namun hasil penelitian tersebut tidak dapat diberlakukan sama pada semua daerah di Indonesia karena masing-masing daerah memiliki pengalokasian dana transfer dari pemerintah pusat yang berbeda beda sesuai dengan kebutuhan daerah masing-masing. Kemudian untuk menanggapi hasil tersebut Armawaddin, dkk melakukan penelitian yang sama pada Belanja Daerah Pemerintah Daerah pada Kabupaten/Kota di Sulawesi tahin 2016-2017 yang kemudian hasilnya konsisten dengan penelitian yang dilakukan Kusumadewi dan Rahman yaitu ditemukannya fenomena flypaper effect yang bersumber dari dana transfer DAU dan DBH

Tabel 1.

Perbandingan PAD terhadap DAU, Belanja terhadap Transfer Pemerintah Kabupaten/Kota di Sumatera Barat Tahun 2018 (Dalam Ribu Rupiah)

\begin{tabular}{|l|c|c|c|}
\hline \multicolumn{1}{|c|}{ Kabupaten/Kota } & PAD & DAU & $\begin{array}{c}\text { \% PAD terhadap } \\
\text { DAU }\end{array}$ \\
\hline Padang Pariaman & 84.502 .722 & 769.827 .010 & $11 \%$ \\
\hline Kepulauan Mentawai & 45.358 .184 & 610.487 .048 & $7 \%$ \\
\hline Pariaman & 32.213 .303 & 415.241 .327 & $8 \%$ \\
\hline Sawahlunto & 47.227 .132 & 501.889 .284 & $9 \%$ \\
\hline Solok Selatan & 60.545 .296 & 480.406 .179 & $12.5 \%$ \\
\hline
\end{tabular}

Sumber: Laporan Realisasi Anggaran tahun 2018 
Tabel diatas merupakan data APBD Pemerintah Kabupaten/Kota di Provinsi Sumatera Barat tahun 2018, dapat dilihat bahwa jumlah pendapatan asli daerah dibandingkan jumlah dana alokasi umum masih sangat kecil, berkisar antara 7 sampai 12,5 persen. Setiap daerah di Sumatera Barat mengalami hal yang sama yakni menerima dana alokasi umum yang lebih besar dari pemerintah pusat dibandingkan pendapatan asli daerahnya sendiri. Hal ini memberikan bukti bahwa semenjak diberlakukannya otonomi daerah, pemerintah daerah masih bergantung kepada pemerintah pusat. Pertanyaannya sekarang adalah apakah penyebab dari flypaper effet sehingga pemerintah daerah masih bergantung kepada pemerintah pusat dalam hal pembiayaan dan belum bisa memperbaikinya.

\section{REVIU LITERATUR DAN PENGEMBANGAN HIPOTESIS Agency Theory}

Teori agensi menjabarkan hubungan antara pihak stakeholder atau principal dengan agent, dimana prinsipal adalah pihak yang memberikan mandat kepada agen. Prinsipal memberikan tanggungjawab kepada agen dalam bentuk perjanjian yang kemudian disepakati oleh kedua pihak dan saling menguntungkan. Teori keagenan menurut Jensen dan Meckling (1976) adalah susunan kontraktual yang dianalsiis antara dua atau lebih individu, kelompok maupun organisasi.

Proses penyusunan Anggaran Pendapatan Belanja Daerah disusun oleh satuan kerja, tim anggaran, dan legislatif seperti DPR yang kemudian membahas usulan rancangan APBD sehingga terjadi kesepakatan antara eksekutif dan legislatif. Disinilah dapat dilihat terjadi hubungan teori keagenan antara eksekutif dengan legislatif dengan eksekutif sebagai agen dan prinsipal oleh legislatif.

\section{Belanja Daerah}

Belanja daerah dalam PSAP No 2 adalah semua pengeluaran daerah yang mengurangi saldo anggaran lebih dalam periode tahun anggaran yang tidak akan diperoleh pembayaran kembali oleh pemerintah.

\section{Flypaper Effect}

Flypaper effect adalah fenomena yang terjadi pada daerah dimana daerah merespon lebih banyak dana transfer yang diberikan oleh pemerintah pusat dibandingkan pendapatan asli daerahnya sendiri dalam hal pembiayaan belanja daerah. Flyapaer effect dibuktikan dengan tingginya koefisien dana transfer dibandingakan pendapatan asli daerah dalam hasil pengujian (Maimunah, 2006).

\section{Dana Alokasi Umum}

Dana alokasi umum atau yang biasa disebut DAU menurut Undang-Undang No 33 tahun 2004 adalah dana yang bersumber dari pemerintah pusat atau APBN yang dialokasikan ke masingmasing daerah di Indonesia dalam hal pemerataan kemampuan keuangan daerah dalam hal peruwjudan otonomi daerah.

\section{Dana Alokasi Khusus}

Dana alokasi khusus adalah dana transfer dari pemerintah pusat yang bersumber dari APBN yang bertujuan untuk mendanai kegiatan dan membantu kebutuhan daerah yang bersifat khusus untuk keperlun daerah dan sesuai yang diutamakan oleh negara atau pemerintah pusat. Halim 
(2012) berpendapat bahwa dengan adanya DAK dapat menutupi dan memenuhi kebutuhan alokasi belanja modal karena cendrung membah aset tetap dari DAK yang dimiliki pemerintah untuk meningkatakan pelayanan publik dan memenuhi kebutuhan pelayanan masyarakat.

\section{Dana Bagi Hasil}

Dana bagi hasil menurut Undang Undang Nomor 33 tahun 2004 adalah dana yang diberikan oleh pemerintah pusat yang bersumber dari APBN yang dialokasikan ke daerah berdasarkan persentase untuk memenuhi kebutuhan darah dalam rangka pelaksanaan desentralisasi.

\section{Pendapatan Asli Daerah}

Pendapatan asli daerah adalah pendapatan daerah yang bersumber dari pajak daerah, retribusi daerah, lain-lain pendapatan asli daerah yang sah dan hasil pengelolaan kekayaan daerah yang dipisahkan yang dipungut sesuai dengan peraturan perundang-undangan.

\section{Pengaruh Dana Alokasi Umum terhadap Belanja Daerah}

Pembiayaan belanja daerah utama selain pendapatan asli daerah adalah dana alokasi umum. Semakin besar dana alokasi umum yang diterima oleh suatu daerah menggambarkan kemandirian daerah tersebut, semakin banyak daerah tersebut menerima dana alokasi umum maka semakin kecil tingkat kemandiriannya atau dapat dikatakan daerah tersebut masih bergantung kepada pemerintah pusat, daerah ini belum mandiri dan belum mampu memenuhi kebutuhan fiskal daerahnya sebagai daerah otonom. Hal ini yang kemudian menyebabkan terjadinya flypaper effect.

Peneitian yang dilakukan oleh Pramuka tahun 2010 menyimpulkan bahwa dana alokasi umum berpengaruh poaitif signifikan terhadap belanja daerah. Penelitian lain dilakukan oleh aprilia dan redo tahun 2013 juga mendapatakan hasil bahwa terdapat pengaruh yang positif dari dana alokasi umum terhadap belanja daerah. Penelitian selanjutnya dilakukan oleh Dul Muid tahun 2014 yang menyatakan bahwa DAU berpengaruh positif dan signifikan terhadap belanja daerah. Teori keagenan yang dikemukakan oleh Jensen dan Meckling dalam Afrianti (2011) menyatakan bahwa pihal yang ikut serta dalam proses penyusunan anggaran cendrung memaksimalkan utilitas manfaatnya dengan cara alokasi sumber daya pada anggaran (Rustiynaingsih, 2012).

$\mathbf{H}_{1}$ : Dana Alokasi Umum berpengaruh positif signifikan terrhadap Belanja Daerah pada Pemerintah Kabupaten/Kota di Provinsi Sumatera Barat

\section{Pengaruh Dana Alokasi Khusus terhadap Belanja Daerah}

Dana transfer yang diberikan oleh pemerintah pusat kepada pemerintah daerah selain dana alokasi umum adalah dan alokasi khusus, yang digunakan untuk pembiayaan yang bersifat khusus dalam rangka pemenuhan kualitas pelayanan masyarakat. Amnah (2014) melakukan menelitian yang berjudul PengaruH PAD, DAU, DAK terhadap pertumbuhan ekonomi dengan belanja modal sebagai variabel intervening di Kabupaten/kota di Aceh. Hasil penelitian tersebut menunjukkan bahwa secara simultan DAK berpengruh signifikan terhadap pertumbuhan ekonomi sendangkan secara parsial DAK berpengaruh tidak signifikan.

Secara tidak langsung DAK berpengaruh tidak signifikan terhadap pertumbuhan ekonomi melalui belanja modal. Penelitian yang dilakukan Rini pada tahun 2014 menyimpulkan bahwa DAK tidak berpengaruh terhadap belanja daerah. Hal ini disebabkan karena DAK adalah bagian 
dari dana perimbangan yang nilainya relatifnya kecil dan hanya digunakan untuk mendanai kegiatan khusus yang menjadi absolut pemerintah pusat.

$\mathbf{H}_{\mathbf{2}}$ : Dana Alokasi Khusus berpengaruh positif signifikan

\section{Pengaruh Dana Bagi Hasil terhadap Belanja Daerah}

Agency theory yang menjadi dasar dalam penelitian ini adalah karena DBH merupakan bagian dari dana transfer yang diberikan oleh pemerintah pusat yang bertujuan untuk pemerataan kemampuan keuangan daerah, namun jumlah yang diberikan kepada daerah tergantung dari kondisi pajak dan sumber daya alam masing-masing daerah. Penelitian Sasana tahun 2010 menjelaskan bahwa koefisien DBH memiliki pengaruh positif terhadap belanja daerah. Penelitian Iskandar (2012) menyimpulkan bahwa unconditional grants memiliki pengaruh signifikan positif terhadap belanja daerah.

Hasil penelitian Riswandi (2014) menyatakan bahwa terjadi flypaper effect di Aceh dikarenakan koefisien DBH terhadap BD lebih tinggi daripada PAD terhadap BD, hal ini berarti bahwa tidak semua DBH memiliki DBH yang tidak lebih besar dibanding dan aloksi umum, dan berdasarkan kondisi dan potensi daerah masing-masing.

H3: Dana Bagi Hasil berpengaruh positif signifikan terhadap Belanja Daerah pada Pemerintah Kabupaten/Kota di Provinsi Sumatera Barat

\section{Pengaruh Pendapatan Asli Daerah terhadap Belanja Daerah}

Pendapatan asli daerah dapat menggambarkan kemandirian suatu daerah. Semakin tinggi jumlah PAD suatu daerah berarti semakin mampu daerah tersebut untuk memenuhi kebutuhan daerahnya dan tidak bergantung kepada pemerintah pusat, dan dapat dikatakan daerah tersebut daerah otonom. PAD adalah salah satu komponen pembiayaan belanja daerah, sehingga peningkatan PAD dapat meningkatkan belanja daerah karena kebutuhan belanja daerah yang juga meningkat.

Hasil penelitian Iskandar (2012) mengungkapkan bahwa hasil koefisien PAD memiliki pengaruh signifikan positif pada belanja daerah. Penelitian selanjutnya dilakukan oleh Oktavia tahun 2014 tang menyatakan bahwa PAD berpengaruh signifikan terhadap belanja daerah dan hasil penelitian ini juga sama dengan penelitian yang dilakukan Rahmawati tahun 2015 .

H4: Pendapatan Asli Daerah berpengaruh positif signifikan terhadap Belanja Daerah pada Pemerintah Kabupaten/Kota di Provinsi Sumatera Barat

\section{Pengaruh DAU, DAK, DBH dibandingkan Pengaruh PAD terhadap Belanja Daerah}

Perbandingan dana transfer dan pendapatan asli daerah menjadi penentu apakah suatu daerah mengalami flypaper effect atau tidak. Flypaper effect terjadi ketika koefisien dana transfer (DAU,DAK, DBH) lebih tiinggi daripada koefisien PAD dalam hasil pengujian. Penelitian tentang topik ini sudah banyak dilakukan. Penelitian yang dilakukan oleh Maimunah tahun 2006 mendapatkan hasil bahwa DAU dan PAD secara serentak berpengaruh signifikan terhadap belanja daerah, pengaruh DAU terhadap belanja daerah lebih kuat dibandingkan pengaruh PAD terhadap belanja daerah, ini berarti terjadi flypaper effect pada daerah penelitian Maimunah yaitu pada Kabupaten/Kota di pulau Sumatera.

Hasil penelitian Tuasikal (2008) menyatakan bahwa dana alokasi umum, dana alokasi khusus dan pendapatan asli daerah berpengaruh positif terhadap belanja modal. Kusumadewi dan Rahman juga melakukan penelitian tahun 2007 yang hasilnya bahwa pengaruh DAU terhadap belanja daerah lebih tinggi koefisiennya daripada pengaruh PAD terhadap belanja daerah. 
Penelitian Prakosa tahun 2004 menyatakan bahwa prediksi DAU lebih tinggi daripada prediksi PAD terhadap belanja daerah.

Hs: Dana Alokasi Umum, Dana Alokasi Khusus, dan Dana Bagi Hasil secara simultan lebih berpengaruh terhadap Belanja Daerah daripada pengaruh Pendapatan Asli Daerah terhadap Belanja Daerah pada Pemerintah Kabupaten/Kota di Provinsi Sumatera Barat

Gambar 1

Kerangka Konseptual

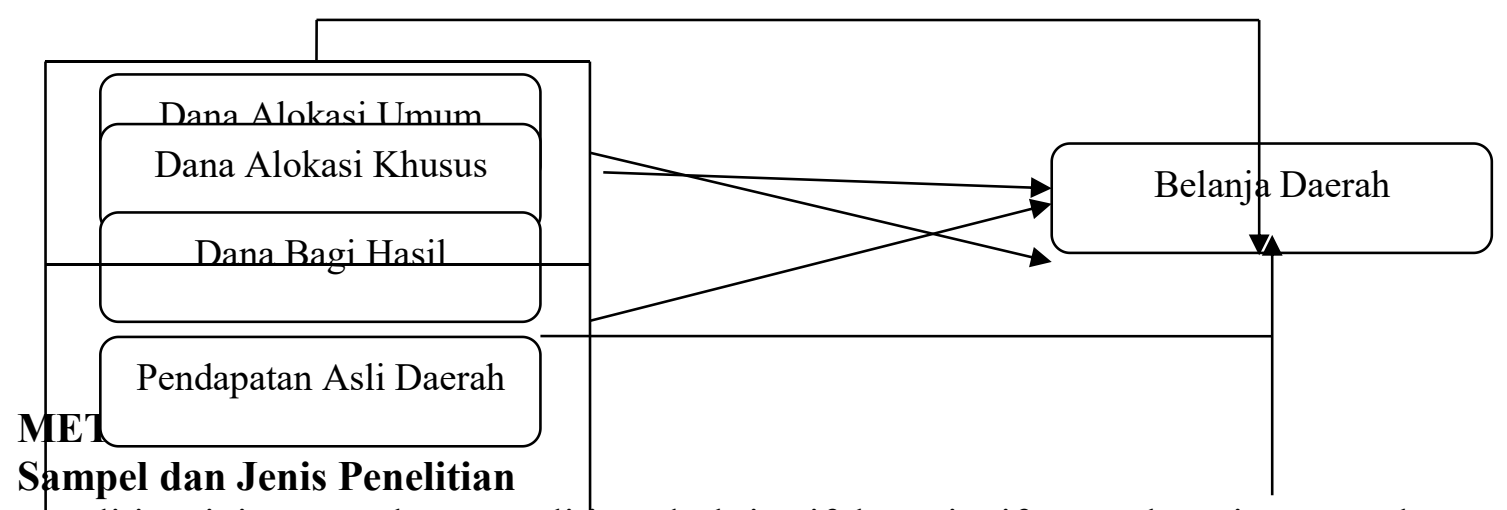

Penelitian ini merupakan penelitian deskrisptif kuantitatif yang bertujuan untuk menjelaskan suatu fenomena empiris yang disertai data statistik, karakteristik dan pola hubungan antar variabel. Populasi dalam penelitian ini Kabupaten/Kota di Provinsi Sumatera Barat tahun 20152018 yang berjumlah 19 Kabupaten/Kota. Sampel dalam penelitian ini adalah total sampling

\section{Jenis, Sumber dan Teknik Pengumpulan Data}

Jenis data yang digunakan dalam penelitian ini adalah data dokumenter dan data sekunder. Metode pengumpulan data yang digunakan dalam penelitian ini adalah studi pustaka dan studi dokumentasi.

\section{Variabel Penelitian dan Pengukuran}

Variabel dependen dalam penelitian ini adalah Belanja Daerah yang diukur dengan menjumlahkan belanja operasi, belanja modal dan belanja tak terduga yang ada dalam LKPD masing-masing daerah. Variabel independen pada penelitian ini adalah dana alokasi umum, dan alokasi khusus, dana bagi hasil dan pendapatan asli daerah. Variabel DAU, DAK dan DBH diukur dengan melihat pos masing-masing variabel di LKPD LRA daerah. Variabel PAD diukur dengan menjumlahkan pajak daerah, retribusi daerah, lain-lain PAD yang sah dan hasil pengelolaan kekayaan daerah yang dipisahkan.

\section{Teknik Analisis Data}

1. Analisis Deskriptif

2. Uji Asumsi Klasik

Uji asumsi klasik yang terdiri dari uji normalitas, uji multikolinieritas, dan uji autokorelasi.

3. Uji Hipotesis

a. Uji Regresi

persamaan regresi pada penelitian ini :

$\mathrm{Y}=\mathrm{a}+\beta 1 \mathrm{X} 1+\beta 2 \mathrm{X} 2+\beta 3 \mathrm{X} 3+\beta 4 \mathrm{X} 4+\mathrm{e}$

b. Uji Koefisien Determinasi 

c. Uji t
d. Uji f

\section{HASIL DAN PEMBAHASAN Analisis Deskriptif}

Tabel 2

Hasil statistik deskriptif

Descriptive Statistics

\begin{tabular}{lr|r|r|r|r|r} 
& $\mathrm{N}$ & \multicolumn{1}{c}{ Minimum } & \multicolumn{1}{c}{ Maximum } & \multicolumn{1}{c}{ Mean } & \multicolumn{1}{c}{ Std. Deviation } \\
\hline BELANJA & 72 & 477505092664 & 1327619178498 & 859661177355.72 & 245789132971.430 \\
\hline DAU & 72 & 343008704000 & 853086000000 & 572559314623.94 & 153705086553.253 \\
\hline DAK & 72 & 15764418000 & 332333000000 & 142327653350.50 & 76689728940.260 \\
\hline DBH & 72 & 9251497286 & 46420598476 & 16457014811.46 & 5743542835.009 \\
\hline PAD & 72 & 29680784158 & 176902866674 & 82163938526.77 & 34468148312.642 \\
\hline $\begin{array}{l}\text { Valid N } \\
\text { (listwise) }\end{array}$ & 72 & & & & \\
\hline
\end{tabular}

Sumber: Data diolah peneliti menggunakan spss 26 tahun 2020

Tabel diatas menunjukkan gambaran statistik deskriptif dari setiap variabel penelitian. Variabel Belanja Daerah memiliki nilai minimum 477505092664, nilai maksimum 1327619178498, nilai rata-rata 859661177355.72 dan nilai standar deviasi sebesar 245789132971.430. Variabel Dana Alokasi Umum memiliki nilai minimum 343008704000, nilai maksimum 853086000000, nilai rata-rata 572559314623.94, dan nilai standar deviasi sebesar 153705086553.253. Variabel Dana Alokasi Khusus memiliki nilai minimum 15764418000, nilai maksimum 332333000000, nilai rata-rata 142327653350.50 , dan nilai standar deviasi sebesar 76689728940.260. Variabel Dana Bagi Hasil memiliki nilai minimum 9251497286, nilai maksimum 46420598476, nilai rata-rata 16457014811.46, dan nilai standar deviasi sebesar 5743542835.009. Variabel Pendapatan Asli Daerah memiliki nilai minimum 29680784158, nilai maksimum 176902866674, nilai rata-rata 82163938526.77, dan nilai standar deviasi sebesar 34468148312.642.

Uji Asumsi Klasik a. Uji Normalias

Tabel 3

Hasil Uji Normalitas One-Sample Kolmogorov-Smirnov Test

Unstanda rdized Residual

\begin{tabular}{llr}
\hline $\mathrm{N}$ & & 72 \\
\hline Normal Parameters ${ }^{\mathrm{a}, \mathrm{b}}$ & Mean & .0000102 \\
\cline { 2 - 3 } & Std. Deviation & 53355116253.27816000 \\
\hline \multirow{2}{*}{ Most Extreme Differences } & Absolute & .080 \\
\cline { 2 - 3 } & Positive & .049 \\
\cline { 2 - 3 } & Negative & -.080 \\
\hline Test Statistic & & .080 \\
\hline Asymp. Sig. (2-tailed) & & $.200^{\mathrm{c}, \mathrm{d}}$ \\
\hline
\end{tabular}

a. Test distribution is Normal. 
b. Calculated from data.

c. Lilliefors Significance Correction.

$\mathrm{d}$. This is a lower bound of the true significance.

\section{b. Uji Multikoliniearitas}

Tabel 4

\section{Hasil Uji Multikolinieritas}

Coefficients $^{\mathbf{a}}$

\begin{tabular}{|c|c|c|c|c|c|c|c|}
\hline \multirow[b]{3}{*}{ Model } & & Coet & Icients & & & \multirow{2}{*}{\multicolumn{2}{|c|}{$\begin{array}{l}\text { Collinearity } \\
\text { Statistics }\end{array}$}} \\
\hline & \multicolumn{2}{|c|}{ Unstandardized Coefficients } & \multirow{2}{*}{$\begin{array}{c}\text { Standardized } \\
\text { Coefficients } \\
\text { Beta }\end{array}$} & & \multirow[b]{2}{*}{ ig. } & & \\
\hline & $\mathrm{B}$ & Std. Error & & & & Tolerance & IF \\
\hline (Constant) & -10032546146.162 & 30399722327.331 & & .330 & 742 & & \\
\hline DAU & 1.305 & .077 & .816 & 6.954 & 000 & .304 & 3.295 \\
\hline DAK & .409 & .142 & .128 & .878 & 005 & .357 & 2.800 \\
\hline $\mathrm{DBH}$ & 1.178 & 1.221 & .028 & 964 & 338 & .864 & 1.158 \\
\hline PAD & .546 & .230 & .077 & .374 & 020 & .677 & 1.478 \\
\hline
\end{tabular}

a. Dependent Variable: BELANJA

\section{c. Uji Heterokedastisitas}

\section{Tabel 5}

Hasil Uji Heterokedastisitas

\section{Coefficients ${ }^{\mathrm{a}}$}

\begin{tabular}{|c|c|c|c|c|c|}
\hline \multirow[b]{2}{*}{ Model } & \multicolumn{2}{|c|}{ Unstandardized Coefficients } & \multirow{2}{*}{$\begin{array}{c}\text { Standardized } \\
\text { Coefficients } \\
\text { Beta }\end{array}$} & \multirow[b]{2}{*}{$\mathrm{T}$} & \multirow[b]{2}{*}{ ig. } \\
\hline & $\mathrm{B}$ & Std. Error & & & \\
\hline (Constant) & 125800799.954 & 20181570577.462 & & 1.195 & 236 \\
\hline $\mathrm{DAU}$ & .051 & .051 & .217 & 997 & 322 \\
\hline DAK & -.075 & .094 & -.160 & -.798 & 428 \\
\hline $\mathrm{DBH}$ & -.678 & .811 & -.108 & -.836 & 406 \\
\hline PAD & .093 & .153 & .089 & .607 & 546 \\
\hline
\end{tabular}

a. Dependent Variable: Abs_Res

\section{d. Uji Autokorelasi}

\section{Tabel 6}

\section{Hasil Uji Autokorelasi} Model Summary ${ }^{b}$

\begin{tabular}{|c|c|c|c|c|c|}
\hline \multicolumn{6}{|c|}{ Model Summary } \\
\hline Model & $\mathrm{R}$ & R Square & Adjusted R Square & $\begin{array}{l}\text { Std. Error of the } \\
\text { Estimate }\end{array}$ & Durbin-Watson \\
\hline 1 & .97 & .95 & .950 & 5492471 & 1.682 \\
\hline & $6^{\mathrm{a}}$ & 3 & & 8976.102 & \\
\hline
\end{tabular}


Hasil uji normalitas dengan menggunakan kolmogorov-smirnov menunjukkan nilai ASYMP.SIG sebesar 0,200 >0,05 yang berari bahwa data terdistribusi dengan normal. Hasil uji multikolinieritas menunjukkan nilai VIF masing-masing variabel terlihat memiliki nilai VIF $<10$ dan nilai tolerance $>0,1$ sehingga bisa dikatakan bahwa tidak terjadi gejala multikolinieritas. Uji heterokedastisitas menunjukkan hasil perhitungan masing-masing variabel menunjukkan bahwa level sig $>0,05$. Jadi dapat disimpulkan bahwa penelitian ini bebas dari gejala heterokedastisitas dan layak untuk diteliti.

Hasil uji autokorelasi menunjukkan nilai DW sebesar 1.682 . Nilai ini akan dibandingkan dengan nilai Tabel Durbin Watson d Statistic : Significance Point For dl and du AT0,05 Level of Significance. Jumlah sampel (N) dalam penelitian ini adalah 72 dan jumlah variabel independennya adalah $4(\mathrm{k}=4)$, maka dari Tabel Durbin Watson akan di dapatkan nilai batas bawah (dl) adalah 1,5029 dan nilai batas atas adalah 1,7366. Jika dilihat dari pengambilan keputusan termasuk $\mathrm{dU}<\mathrm{dW}<4-\mathrm{dU}(1,572<1,682<4-1,7366)$, dapat disimpulkan tidak terjadi autokorelasi antar variabel independen, sehingga model regresi layak digunakan.

\section{Uji Hipotesis}

\section{a. Uji Regresi Linier Berganda}

Tabel 7

\begin{tabular}{|c|c|c|c|c|c|c|c|}
\hline \multirow[b]{3}{*}{ Model } & \multicolumn{7}{|c|}{$\begin{array}{c}\text { Hasil Uji Regresi } \\
\text { Coefficients }^{\mathrm{a}}\end{array}$} \\
\hline & \multicolumn{2}{|c|}{ Unstandardized Coefficients } & \multirow{2}{*}{$\begin{array}{c}\text { Standardized } \\
\text { Coefficients } \\
\text { Beta }\end{array}$} & & \multirow[b]{2}{*}{ ig. } & \multicolumn{2}{|c|}{ Collinearity Statistics } \\
\hline & B & Std. Error & & & & Tolerance & VIF \\
\hline (Constant) & -10032546146.162 & 30399722327.331 & & .330 & 742 & & \\
\hline $\mathrm{DAU}$ & 1.305 & .077 & .816 & 6.954 & 000 & 304 & .295 \\
\hline DAK & .409 & .142 & .128 & .878 & 005 & 357 & .800 \\
\hline $\mathrm{DBH}$ & 1.178 & 1.221 & .028 & 964 & 338 & 864 & .158 \\
\hline PAD & .546 & .230 & .077 & .374 & 020 & 677 & .478 \\
\hline
\end{tabular}

a. Dependent Variable: BELANJA

Sumber : Olahan data SPSS26 2020

\section{b. Uji f dan uji koefisien determinasi}

\begin{tabular}{|c|c|c|c|c|c|}
\hline \multirow[b]{2}{*}{ Model } & & \multicolumn{4}{|c|}{$\begin{array}{c}\text { Tabel } 8 \\
\text { Hasil Uji f } \\
\text { ANOVA }^{\mathrm{a}}\end{array}$} \\
\hline & & Sum of Squares & $\mathrm{f}$ & Mean Square & $\mathrm{F}$ ig. \\
\hline$\overline{1}$ & Regression & $\begin{array}{r}40701468141168466 \\
00000000.000\end{array}$ & & $\begin{array}{r}13567156047056156 \\
00000000.000\end{array}$ & $421.020000^{b}$ \\
\hline & Residual & $\begin{array}{r}21912633584930026 \\
0000000.000\end{array}$ & 8 & $\begin{array}{r}32224461154308860 \\
00000.000\end{array}$ & \\
\hline & Total & $\begin{array}{r}42892731499661470 \\
00000000.000 \\
\end{array}$ & 1 & & \\
\hline
\end{tabular}


Tabel 9

\begin{tabular}{|c|c|c|c|c|}
\hline \multirow{3}{*}{ Model } & \multicolumn{4}{|c|}{$\begin{array}{c}\text { Hasil Uji Koefisien Determinasi simultan } \\
\text { Model Summary }\end{array}$} \\
\hline & $\mathrm{R}$ & R Square & Adjusted R Square & $\begin{array}{l}\text { Std. Error of the } \\
\text { Estimate }\end{array}$ \\
\hline & $.974^{\mathrm{a}}$ & .949 & .947 & 56766593304.785 \\
\hline
\end{tabular}

Tabel 10

Hasil Uji Koefisien Determinasi PAD Model Summary

\begin{tabular}{|c|c|c|c|c|}
\hline \multirow{3}{*}{ Model } & & & & \\
\hline & $\mathrm{R}$ & R Square & Adjusted R Square & $\begin{array}{l}\text { Std. Error of the } \\
\text { Estimate }\end{array}$ \\
\hline & $.595^{\mathrm{a}}$ & .353 & .344 & 199035912953.314 \\
\hline
\end{tabular}

Tabel 11

Hasil Perbandingan Uji F (DAU, DAK, DBH) dengan Uji t (PAD) terhadap BD

\begin{tabular}{|l|c|c|}
\hline Variabel & Uji F & Adjusted R Square \\
\cline { 1 - 1 } DAU & \multirow{2}{*}{421.020} & 0,947 \\
\cline { 1 - 1 } DAK & & \\
\cline { 1 - 1 } DBH & & 0,344 \\
\hline PAD & & \\
\hline
\end{tabular}

Hasil uji Hipotesis 1 : Dari hasil uji hipotesis pertama diperoleh nilai t sebesar 16,954 dan nilai koefisien regresi positif sebesar 1,305 dengan nilai signifikansi sebesar $0,000<\alpha(0,05)$, artinya Dana Alokasi Umum berpengaruh positif dan signifikan terhadap Belanja Daerah, maka dapat disimpulkan hipotesis pertama diterima. Hasil uji Hipotesis 2 : Hasil uji hipotesis kedua diperoleh nilai t sebesar 2,878 dan nilai koefisien regresi positif sebesar 0,409 dengan nilai signifikansi sebesar $0,005<\alpha(0,05)$, artinya Dana Alokasi Khusus berpengaruh positif dan signifikan terhadap Belanja Daerah, maka dapat disimpulkan hipotesis kedua diterima. Hasil uji Hipotesis 3 : Hasil dari uji hipotesis ketiga diperoleh nilai t sebesar 0,964 dan nilai koefisien regresi sebesar 1,178 dengan nilai signifikansi sebesar 0,338 $>\alpha(0,05)$, artinya Dana Bagi Hasil tidak berpengaruh terhadap Belanja Daerah sehingga dapat disimpulkan bahwa hipotesis ketiga ditolak.

Hasil uji Hipotesis 4 : Hasil dari uji hipotesis keempat diperoleh nilai t sebesar 2,374 dan nilai koefisien regresi sebesar 0,546 dengan nilai signifikansi sebesar $0,020<\alpha(0,05)$, artinya variabel Pendapatan Asli Daerah berpengaruh positif dan signifikan terhadap Belanja Daerah sehingga dapat disimpulkan bahwa hipotesis keempat diterima. Hasil uji Hipotesis 5 : Hasil tabel diatas menunjukkan hasil Uji F pada DAU, DAK, DBH menunjukkan nilai Fhitung sebesar 421,02 dengan nilai Ftabel sebesar 2,51 Karena Fhitung > Ftabel maka dapat dinyatakan bahwa DAU, DAK dan DBH secara serentak berpengaruh positif terhadap belanja daerah. Tabel diatas menunjukkan nilai Adjusted R Square DAU, DAK DBH secara simultan terhadap Belanja Daerah sebesar 0,947 yang artinya bahwa DAU, DAK dan DBH secara simultan berpengaruh terhadap Belanja Daerah. Sedangkan nilai R Square PAD terhadap Belanja Daerah sebesar 0,344. 
Dari hasil perbandingan tersebut, pengaruh simultan DAU, DAK, DBH terhadap BD lebih besar dibanding pengaruh PAD terhadap Belanja Daerah, dengan kata lain hipotesis kelima diterima. Hal ini menunjukkan bahwa terjadi fenomena flypaper effect pada DAU, DAK, DBH dan PAD terhadap BD Kabupaten/Kota di Sumatera Barat.

\section{PEMBAHASAN}

\section{Pengaruh Dana Alokasi Umum Terhadap Belanja Daerah}

Hipotesis pertama menyatakan bahwa Dana Alokasi Umum berpengaruh positif signifikan terhadap Belanja Daerah pada Pemerintah Kabupaten/Kota di Sumatera Barat. Berdasarkan hasil pengujian yang dilakukan menunjukkan bahwa Dana Alokasi Umum berpengaruh positif dan signifikan terhadap pengalokasian anggaran Belanja Daerah pada pemerintah Kabupaten/Kota di Sumatera Barat yang ditunjukkan dengan nilai sig dari DAU yang lebih kecil dari nilai 0,05, yang bermakna bahwa semakin besar DAU maka semakin besar pula Belanja Daerah.

\section{Pengaruh Dana Alokasi Khusus Terhadap Belanja Daerah}

Hipotesis kedua menyatakan bahwa Dana Alokasi Khusus berpengaruh positif signifikan terhadap Belanja Daerah pada Pemerintah Kabupaten/Kota di Provinsi Sumatera Barat. Dengan melihat hasil uji hipotesis kedua, diketahui bahwa DAK berpengaruh positif signifikan terhadap Belanja Daerah, hasil ini sejalan dengan penelitian yang dilakukan oleh Sukartono pada tahun 2010 yang menyatakan bahwa DAK berpengaruh positif terhadap Belanja Daerah.

\section{Pengaruh Dana Bagi Hasil Terhadap Belanja Daerah}

Hipotesis ketiga menyatakan bahwa Dana Bagi Hasil berpengaruh positif signifikan pada Belanja Daerah pada Pemerintah Kabupaten/Kota di Provinsi Sumatera Barat. Berdasarkan hasil pengujian yang dilakukan membuktikan bahwa Dana Bagi Hasil tidak berpengaruh signifikan terhadap Belanja Daerah pada Pemerintah Kabupaten/Kota di Sumatera Barat, yang ditunjukkan oleh nilai sig dari Dana Bagi Hasil 0,338 > 0,05. Hal ini disebabkan oleh DBH yang merupakan salah satu Dana Perimbangan namun pengalokasiannya berbeda dengan DAU dan DAK, pengalokasian DBH tergantung dari Pajak dan Sumber Daya Alam masing-masing, hal ini berarti apabila perolehan pajaknya antara lain PBB,BPHTB, Pajak Penghasilan WP,OP serta sumber daya alamnya yang sedikit maka secara otomatis DBH nya pun sedikit.

\section{Pengaruh Pendapatan Asli Daerah Terhadap Belanja Daerah}

Hipotesis keempat menyatakan Pendapatan Asli Daerah berpengaruh positif signifikan terhadap Belanja Daerah pada Pemerintah Kabupaten/Kota di Provinsi Sumatera Barat. Berdasarkan hasil uji tes yang dilakukan membuktikan bahwa PAD berpengaruh positif dan signifikan terhadap Belanja Daerah pada pemerintah Kabupaten/Kota di Sumatera Barat, nilai sig dari PAD yang lebih kecil dari nilai $\alpha 0,05$, hal ini disebabkan karena adanya peningkatan PAD yang dikelola oleh daerah membuat masyarakat sadar dan wajib pajak serta seimbang dalam pelayanan publik serta fasilitasnya, hal ini mengindikasikan bahwa kenaikan PAD juga akan mempengaruhi Belanja Daerah

Pengaruh DAU, DAK, DBH terhadap Belanja Daerah dibandingkan Pengaruh PAD terhadap Belanja Daerah serta Analisis Flypaper Effect pada Pemerintah Kabupaten/Kota di Sumatera Barat 
Hasil pengujian pada hipotesis kelima yang menunjukkan hasil Uji F pada DAU, DAK, DBH menunjukkan nilai $\mathrm{F}$ hitung sebesar 421,02 dengan nilai Ftabel sebesar 2,51 Karena Fhitung > Ftabel maka dapat dinyatakan bahwa DAU, DAK dan DBH secara serentak berpengaruh signifikan positif terhadap belanja daerah. Tabel diatas menunjukkan nilai Adjusted R Square DAU, DAK DBH secara simultan terhadap Belanja Daerah sebesar 0,947 yang artinya bahwa DAU, DAK dan DBH secara simultan berpengaruh terhadap Belanja Daerah sebesar 94,7\%. Sedangkan nilai Adjusted R Square PAD terhadap Belanja Daerah sebesar 0,344, yang berarti bahwa PAD berpengaruh terhadap Belanja Daerah sebesar 34,4\%. Dari hasil perbandingan tersebut, pengaruh simultan DAU, DAK, DBH terhadap BD lebih besar dibanding pengaruh PAD terhadap Belanja Daerah, dengan kata lain koefisien dana transfer lebih besar daripada koefisien Pendapatan Asli Daerah. Hal ini menunjukkan bahwa terjadi fenomena flypaper effect pada DAU, DAK, DBH dan PAD terhadap BD Kabupaten/Kota di Sumatera Barat.

\section{KESIMPULAN DAN IMPLIKASI}

Berdasarkan hasil dan pembahasan yang dilakukan maka dapat disimpulkan bahwa secara parsial DAU, DAK dan PAD berpengaruh positif terhadap Belanja Daerah namun DBH tidak berpengaruh terhadap belanja daerah. Telah terjadi flypaper effect pada pemerintah kabupaten/kota di Sumatera Barat. Hal ini menunjukkan bahwa pemerintah daerah di Sumatera Barat masih bergantung kepada pemerintah pusat.

Implikasi dalam penelitian ini adalah agar pemerintah daerah menekan tingkat ketergantungan kepada pemerintah pusat dengan meningkatkan pendapatan asli daerah tanpa harus menyusahkan masyarakat seperti menaikkan pajak, tapi pemerintah bisa melakukan peningkatan tempat wisata dan meningkatkan jumah kuliner halal di Sumatera Barat untuk menaikkan pendapatan daerah dan meningkatkan sektor ekonomi daerah. Saran untuk penelitian selanjutnya adalah agara meningkatkan jangkauan daerah untuk diteliti serta melihat faktor lain seperti faktor internal terjadinya flypaper effect serta menambah jenis data dengan melakukan wawancara dengan pihak terkait dalam penyusunan DAU.

\section{DAFTAR PUSTAKA}

Ardiansyah, dkk. (2014). Pengaruh Pendapatan Asli Daerah, Dana Alokasi Umum, dan Dana Alokasi Khusus terhadap Indeks Pembangunan Manusia Kabupaten/Kota Provinsi Jawa Tengah. Jurnal SNA 17.

Halim, A. (2012). Pengelolaan Keuangan Daerah. Yogyakarta: STIM YKPN.

Kusumadewi, Diah A dan Arief R. (2007). Flypaper Effect pada Dana Alokasi Umum (DAU) dan Pendapatan Asli Daerah (PAD) terhadap Belanja Daerah pada kabupaten/Kota di Indonesia. JAAI, 11(1).

Maimunah, M. (2006). Flypaper Effect pada Dana Alokasi Umum (DAU) dan Pendapatan Asli Daerah (PAD) terhadap Belanja Daerah pada kabupaten/Kota di pulau Sumatera. Simposium Nasional Akuntansi IX, Padang.

Octavia, Deny. 2014. Flypaper Effect Fenomena Serial Waktu dan Lintas Kabupaten Kota di Jawa Timur 2003-2013. Jurnal Akuntansi Universitas Jember Vol.12 No.2.

Tuasikal. (2008). Pengaruh DAU, DAK, PAD, dan PDBR terhadap Belanja Modal Pemerintah Daerah Kabupaten/Kota di Indonesia. Jurnal Telaah dan Riset Akuntansi, 1(2)

Undang-Undang Nomor 32 Tahun 2004 tentang Pemerintah Daerah. 
Undang-Undang Nomor 33 Tahun 2004 tentang Perimbangan Keuangan antara Pemerintahan Pusat dan Pemerintah Daerah 